Ankara Üniversitesi Türk İnkllâp Tarihi Enstitüsü Atatürk Yolu Dergisi S 48, Güz 2011, s. 733-748

\title{
Atatürk Dönemi Sağlık Politikası
}

\author{
Doç. Dr. İsmail AĞIRBAȘ* \\ Yrd. Doc. Dr. Yasemin AKBULUT* \\ Doç. Ömer Rıfkı ÖNDER*
}

\section{$\ddot{O} z e t$}

Cumhuriyetin ilk yıllarında diğer alanlarda olduğu gibi sağlık alanında da evrensel bir politikanın var olduğu görülmektedir. Bugün sağlık uygulamalarının temelini oluşturan yasalar 1928,1930 ve 1933 tarihinde yürürlüğe girmiştir. Tüm dünyada üzerinde önemle durulan; koruyucu sağlık hizmeti anlayışının, sağlık eğitimi, toplum katılımı ve öncelik belirleme gibi yaklaşımların bu dönemin sağlık politikasına yön verdiği görülmektedir. Bu politikaların yürütülmesinde belirleyici olan ise, Atatürk'ün sağlık ve să̆lık hizmetlerine bakış açısıdır. Sınırlı sayıdaki çalıșmalar dıșında bu bakıș açısı yeterince değerlendirilmemiștir. Sağlık sektöründe çok önemli değişimlerin yaşandı̆̆ bir dönemde bu değerlendirmenin yapılması yararlı olacaktır. Değerlendirme yapılırken dönemin, 1. Dünya Savaşı sonrası olduğu, ulusal kurtuluş savaşını kapsadı̆̆l, 1929 dünya ekonomik bunalımının yaşandı̆̆l ve 2. Dünya Savaşıııın öncesi olduğu unutulmamalıdır.

Anahtar Kelimler: Mustafa Kemal Atatürk, sağlık politikası, să̆lık yönetimi, Türkiye Cumhuriyeti.

\section{Absract}

\section{Health Policy in The Period of Atatürk}

In the early years of Republic, in the field of health as in other areas it is seen that there is a universal policy. Today, the laws that form the basis of medical

\footnotetext{
*Ankara Üniversitesi Sağlık Bilimleri Fakültesi Sağlık Kurumları Yöneticiliği Bölümü,
} ANKARA 
practices went into effect in 1928, 1930 and 1933. The approaches including understanding of preventive health services, health education, community participation and priority setting that are crucial to the whole world are seen directing the health policy of this period. The perspective of Ataturk to health and health services is the decisive factor in determining the conduct of these policies. Except for a limited number of studies this perspective is not assessed. This assessment will be useful in a period of very significant changes in the health sector. During evaluation, it should be noted that the period covered the National Liberation War and the time after First World War, the world economic crisis occur and pre-World War II.

Key words: Mustafa Kemal Atatürk, health policy, health management, Republic of Turkey.

\section{Giriş}

Toplumu oluşturan bireylerin ve dolayısıyla toplumun en büyük zenginliği sağlığıdır. Sağlık sektörü stratejik bir sektördür. Çünkü sağlıksız toplumların gelişmesi, kalkınması ve çağdaş uygarlık düzeyine ulaşması mümkün görülmemektedir. Bu nedenle, sağlık sorunlarını belirli düzeyde çözmüş olan ülkelerde genel olarak ekonomik, siyasal ve sosyal konularda önemli gelişmeler sağlanmıştır.

Birey ve toplum yaşamında önemli bir yeri olan sağlık ve sağllk hizmetleri kamu ve özel sektör tarafından yürütülen politikalardan etkilenmektedir. Yürütülen politikalar ise kaynağını benimsenen felsefeden almaktadır. Felsefe; bir bilim ya da bilgi alanının temelini oluşturan kavramlar, değerler ve ilkeler bütünüdür. Sağlı alanının kavramları, değerleri ve ilkelerinden oluşan bütün sağlık felsefesini oluşturur. Politika ise; toplum yaşamının her bir alanını, benimsenen felsefe doğrultusunda düzenlemek ve yapılandırmaktır. Sağlık politikalarına bakıldığında genelde iki felsefeden hareket edilerek, iki ayrı seçeneğin belirginleştiği görülmektedir. $\mathrm{Bu}$ seçeneklerden birisi sağlı̆̆ toplumsal olgu, sağlıklı yaşam ve tıbbi bakımı doğuştan kazanılmış temel bir insan hakkı, sağlık hizmetlerini ise toplumsal bir görev ve sorumluluk olarak gören politikadır. $\mathrm{Bu}$ politika, sağlık hakkının gereklerinin yerine getirilmesi görevini toplumun örgütlü gücü olan devlete verir. Sağllk hizmetlerini toplumsal dayanışmanın ve ulusal geliri yeniden dağıtmanın bir aracı olarak ele alır ve hizmetlerden yararlanma eşitliği öngörür. Diğer seçenek ise; sağlığı bireysel olgu olarak gören, sağlık hakkının gereklerinin yerine getirilmesini toplumsal bir görev olarak değil, bireysel sorumluluk olarak tanımlayan ve bu hakkın yerine getirilmesini piyasanın arz ve talep kurallarına bırakarak 
insanların bu haktan firsatları ölçüsünde yararlanmasını öngören, sağlık hizmetlerini kâr aracı olarak kabul eden politikadır. Sağlık sektörünü benimsenen felsefe doğrultusunda düzenlemek ve yapılandırmak işlevi sağlık politikasına aittir. Sağlık sektörünü yapılandırmanın araçları ise; örgütlenme, finansman ve insan gücüdür. $\mathrm{Bu}$ araçları biçimlendirme yöntemleri ikincil (alt) sağlık politikalarını oluşturur. Bu politikalar, ülkeler arasında ve ülke içinde farklı yapılanmalara neden olabilir. ${ }^{1}$ Politikanın yazılı ve açık olması ön koşul olmadığı gibi, bazen yalnızca uygulananlar değil de yapılmayanlar da politikanın bir parçasını oluşturmaktadır. Örneğin hekimlerin yarı zamanlı olarak muayenehanelerinde çalışmalarına izin vermek, geri ödeme kurumlarının sağlık hizmetlerini özel sağlık kurumlarından almasını teşvik etmek gibi politikalar bir araya geldiğinde, sağlık hizmetlerinde özel sektörün payını artırma yönünde gizli bir politikanın temelini oluşturabilir. Benzer biçimde, Amerika Birleşik Devletleri'nde herkesi kapsayan sosyal bir sigorta sistemine geçilmemesi sağlık ihtiyaçlarını karşılamada özel sektöre dayalı politikanın yansıması olarak yorumlanmaktadır. ${ }^{2}$

Sağlığın birçok faktörden etkileniyor olması, bu konuda yapılacak hizmetlerin ve alınacak politik kararların çok yönlü olmasını da zorunlu kılmaktadır. Yalnızca hastaların tedavisi ve kişiye yönelik sağlığ geliştirmeyi öngören programların beklenen sonucu vermeyeceği ifade edilmektedir. Sağlığa zarar vermeyen bir çevrenin oluşturulması ve korunması, dengeli beslenmenin, sağlığı destekleyen konut, çalışma ve dinlenme koşullarının sağlanması, bir sağlık planı hazırlanırken göz önüne alınması gereken konular olarak ele alınmaktadır.

Bu çalışmada 1920 - 1945 yılları "Atatürk Dönemi” olarak ele alınmıştır. Dr. Refik Saydam çok kısa aralıklar dışında, Atatürk döneminde Sağlık Bakanı olarak görev yapmıştır. Atatürk'ün ölümünden sonra, kısa bir süre İç İşleri Bakanlığı, 25 Ocak 1939 ve 7 Temmuz 1942 tarihleri arasında da başbakan olarak görev yapmıştır. Dolayısı ile izlenen sağlık politikaları Atatürk'ün ölümünden sonra da devam etmiştir. Ancak İkinci Dünya Savaşı'nın bitimi ile 1945 yılından sonra sağlık politikasında değişimler gözlenmeye başlanmıştır.

\footnotetext{
${ }^{1}$ Recep Akdur; Sağlık Sektörü Temel Kavramlar, Türkiye ve Avrupa Birliği'nde Durum ve Türkiye'nin Birliğe Uyumu, Ankara Üniversitesi Avrupa Toplulukları Araştırma ve Uygulama Merkezi Araștırma Dizisi No:17, Ankara, 2003, s. 17-18.

${ }^{2}$ Mehtap Tatar; "Sağlık Politikası Nedir?”, Makro Bakış, 2, 2006, s 22.

${ }^{3}$ Nusret Fișek; "Türkiye Cumhuriyeti Hükümetlerinde Sağllk Politikaları", Toplum ve Hekim, Say1: 48, 1991, s. 2.
} 
Bu çalışmanın amacı, Atatürk dönemi (1920-1945) sağlı politikasını, bu günün koşulları 1şığında değerlendirmektir. $\mathrm{Bu}$ amaçla, dönemin yasal düzenlemeleri ve hayata geçirilen sağlık uygulamaları Türkiye Büyük Millet Meclisi (TBMM) tutanakları, Atatürk'ün konuşmaları ve literatür bilgileri kapsamında incelenmiştir. Çalışmada konu bütünlüğünü sağlamak amacıyla öncelikle Osmanlı İmparatorluğu döneminde var olan sağlı politikası ve uygulamalarına özet olarak yer verilecektir.

\section{Osmanlı İmparatorluğu Dönemi}

İmparatorluk döneminde monarşinin özellikleri sağlı politikası ve uygulamalarına da yansımıştır. Sağlık hizmetleri daha çok saraya ve orduya yönelik olarak yürütülmüştür. Devletin tek resmi sağlık örgütü, sarayda yer alan Hekimbaşılık kurumudur. Padişahın ve ailesinin sağlığından sorumlu olan hekimbaşı aynı zamanda devletin sağlık işlerini düzenlemekle görevlidir. İdari gelişmeler sonucunda hekimbaşılık 1850 yılında kaldırılmış ve bu görevde bulunanlar Sertabip adıyla saray çevresinin sağlık işleriyle ilgilenmişlerdir. Bunun yanında, kimsesiz ve yoksul kişiler için, padişah ve yakınlarının, bazı vakıfların kurduğu hastane ve şifa evleri sağlık hizmeti sunmuştur. Bu hizmetler büyük kentlerle sınırlı kalmıştır., ${ }^{4,5}$

19. yüzyıl başlarında batı ile kurulan yeni ilişkiler sonucunda, devletin sağlık hizmetlerine olan ilgisi artmıştır. Bu doğrultuda, 1827 yılında askeri tıp okulu açılmış, 1838 yılında Karantina Örgütü ve ilk sağlı mevzuatı olan "Karantina Talimatnamesi" yürürlüğe girmiştir. Bu talimatname doğrultusunda salgın hastalıkların batı ülkelerine taşınmasını önlemek amacı ile yabancı ülke temsilcilerinin ve hekimbaşının içinde bulunduğu kurumsal bir yapı oluşturulmuştur. $\mathrm{Bu}$ uygulama Osmanlı Devleti'nin kıyı ve limanlarındaki ticaret ve denizcilik faaliyetlerinin denetlenmesine dönüşerek bir kapitülasyon unsuru haline gelmiştir. İki Türk üye ve on dört yabanc1 üyenin yer aldığı Karantina Örgütü, Lozan Barış Anlaşmasının 114. maddesi ile kaldırılmıştır. Bugünkü sağlık teşkilatının ilk çekirdeği, 1871 yılında taşraya (İl ve İlçelere) "Memleket Tabibi" adıyla hekim atanmasıyla ekilmiştir. Memleket tabiplerinin görevleri, koruyucu ve tedavi edici sağlik hizmetleri ve adli tabiplik olarak belirtilmiştir. Memleket tabipleri yerel mülki amirden çok merkezden emir almış ve mülki amir danışmanı niteliğinde görev yapmışlardır. Ancak memleket tabiplerinin maaşı ve gerekli diğer harcama bedellerini ödemekle belediyeler yükümlü kılınmıştır. Yaşanan sorunlar nedeniyle, 1888 yılından itibaren tabiplerin maaşları

\footnotetext{
${ }^{4}$ Akdur, a.g.e., s.22-24.

5 Erdem Aydın; Türkiye'de Sağlık Teşkilatlanması Tarihi, Naturel Yayınları, Ankara, 2002, s. $7-8$
} 
doğrudan devlet tarafindan ödenmeye başlanmıştır. Bu uygulamalar devam ederken 1906 yılında Meclis-i Maarifi Sihhiye kurulmuş, bu meclis 1908 yılında Meclis-i Umuru Tıbbiye-i Umumiye (Sağlık İşleri Genel Müdürlüğü) adını alarak genel müdürlüğe eşdeğer bir statüye kavuşturulmuştur. 1913 yılında önemli bazı yeni düzenlemeler yapılmıştır. Bu kapsamda; öncelikli görevleri bayındırlık ve sağlık hizmetleri olan il özel idareleri kurulması, illerde sağlık müdürlükleri, il ve ilçelerde sihhiye meclisleri kurulması ve memleket tabipliği unvanından vazgeçilerek yerine hükümet tabipliği unvanı kullanılmasına karar verilmiştir. Sağlık müdürlüğü ilin sağlık hizmetlerinden sorumlu kurum olarak görev yapmaktadır. Bu kurum, günümüzde de aynı işlevi sürdürmeye devam etmektedir. $\mathrm{Bu}$ dönemde oluşturulan sıhhiye meclislerinin görevi, ilçelerinin sağlik sorunlarını görüşerek gerekli girişimleri yapmaktır. Bu meclislerin haftada bir, gerekirse daha sık toplanması zorunlu tutulmuştur. Yerine göre vali, kaymakam, belediye başkanı, hükümet tabibi, mühendis, lise müdürü, eczacı, veteriner, eğitim müfettişi gibi görevlilerin yer aldığı bu meclisler toplum katılımı ve sektörler arası işbirliğinin örneğini oluş̧urmaktadır. Daha önce kurulmuş olan Meclis-i Umuru Tibbiye-i Umumiye (Sağlık İşleri Genel Müdürlüğü) 1914 yılında Dâhiliye Nezaretine (İç İşleri Bakanlığı) bağlanarak Dâhiliye Nezareti’nin adı "Dâhiliye ve Sihhiye Nezareti”" olarak değiştirilmiştir. ${ }^{6,7,8}$

\section{Cumhuriyet Dönemi}

Türkiye Cumhuriyeti sağlık politikalarının gelişimi, politikaların özellikleri dikkate alınarak, genellikle dört dönem halinde incelenmektedir. Bu dönemler;

1) $1920-1945$,

2) 1945 - 1960,

3) $1960-1980$,

4) 1980 ve sonrası yılları kapsamaktadır. Bu çalışmada 1920 - 1945 yılları "Atatürk Dönemi” olarak ele alınmıştır.

\subsection{Mustafa Kemal Atatürk Dönemi}

Cumhuriyetin ilk yıllarında, diğer alanlarda olduğu gibi sağlık alanında da çok olumlu bir politikanın var olduğu görülmektedir. Bugün sağlik uygulamalarının temelini oluşturan yasalar 1928, 1930 ve 1933 tarihinde

\footnotetext{
${ }^{6}$ Akdur, a.g.e., s. 23-24.

${ }_{8}^{7}$ Aydın, 2002, a.g.e., s. 7-11.

8 Türkiye Cumhuriyeti Sıhhat ve İçtimai Muavenet Vekâleti; Sıhhiye Mecmuası Fevkalade Nüshası, Vekâletin 10 yıllık Mesaisi, Hilal Matbaası, İstanbul, 1933, s.14-15.
} 
yürürlüğe girmiştir. O dönemin politikası içinde iki önemli konu olan milli eğitim ve sağlığın birlikte ele alındığı görülmektedir. Sağlıklı olmada halk eğitiminin ne denli önemli olduğundan yola çıkılarak, okuma yazma eğitimi ile halk sağlığı eğitimi birlikte yürütülmüştür. Alfabede içilen suyun nasıl olması gerektiği, temizliğin ve aşının ne olduğu anlatılmıştır. Cumhuriyetin ilk alfabesinde okuma yazma ile birlikte sağlığın temel kuralları da öğretilmiştir. ${ }^{9}$

Sağlık hizmetlerinin devletin temel görevlerinden biri olarak ele alınması 23 Nisan 1920 tarihinde TBMM'nin kurulması ile başlamaktadır. TBMM'nin kuruluşundan yalnızca dokuz gün sonra, 2 Mayıs 1920 tarih ve 3 sayılı kanun ile Sağlık ve Sosyal Yardım Bakanlığı (SSYB) kurulmuştur. Bu yıllarda, ülkenin büyük bölümünün işgal altında olduğu, işgali sonlandırmak için ulusal bir kurtuluş savaşı başlatılacağı, ancak bunun için düzenli bir ordunun olmadığı bilinmektedir. Böyle bir ortamda Mustafa Kemal Atatürk ve arkadaşları orduyu kurmadan SSYB'nı kurmuşlardır. Bu durum, sağlıksız bir toplum ve ordu ile ulusal kurtuluş savaşında başarılı olunamayacağına olan inancin bir göstergesidir. $\mathrm{Bu}$ yaklaşım, sağl1k sektörünün stratejik önemine vurgu yapmaktadır. SSYB'nın kuruluş kanunu ile ilgi görüşmelere 1 Mayıs 1920 tarihinde başlanmıştır. Görüşmeler sırasında önemli tartışmalar yaşanmış ve bazı milletvekilleri ayrı bir bakanlığa ihtiyaç olmadığını, İçişleri Bakanlığı bünyesinde devam etmesi gerektiğini, bazı milletvekilleri sosyal yardımın bu bakanlık ile ilişkilendirilmemesi gerektiğini savunmuşlardır. Oysa Atatürk, bakanlığın adının SSYB olması gerektiğini vurgulamış, böylece sağlığın iyileştirilmesinde sosyal yardımın önemine dikkat çekmiştir. Dünya Sağlik Örgütü'nce (DSÖ) 1940'lı yıllarda sağlık, "yalnızca hastalık ve sakatlığın olmayışı değil, insanların bedenen, ruhen ve sosyal yönden tam bir iyilik hali" olarak tanımlanmıştır. Bu durum, Atatürk'ün sosyal gelişme ile sağlığın ilişkisini DSÖ'den yıllar önce ortaya koyduğunu göstermektedir. Bakanlığın kurulmasını savunan milletvekilleri ise, sağlık olmadan iç işlerinin, milli mücadelenin, ziraatın, ticaretin yürütülemeyeceğini, ibadetin bile yapılamayacağını ve hastalıklar nedeniyle milletin varlığını devam ettirmenin tehlikeye gireceğini, bu nedenle ayrı bir bakanlığın gerekli olduğunu savunmuşlardır. Görüşmelerde tartışmalar sonrası Mustafa Kemal Atatürk söz alarak tarafları yatıştırıcı bir konuşma yapmıştır. Görüşmeler, 2 Mayıs 1920 de kanunun kabulü ile sonuçlanmıştır. ${ }^{10}$ Mecliste yaşanan tartışmalara karşın, SSYB'nın kurulmuş

\footnotetext{
${ }^{9}$ Suat Çağlayan; "Sağlık Yönetimi ve Sağlıkta Yeniden Yapılanma", Yeni Türkiye, Sağlık Özel Sayısı, Say1: 40, Temmuz - Ağustos, Ankara, 2001, s.1197.

10 TBMM; "Zabit Ceridesi", 1.5.1336 1 Mayı 1920, s. $163-167$ (tbmm.gov.tr/tutanaklar/TUTANAK, erişim tarihi:11.07.2011)
} 
olması Mustafa Kemal Atatürk'ün sağlığa verdiği önemin bir göstergesidir. $\mathrm{Bu}$ tartışmalar; bireyin ve toplumun sağlık sorunları ile ekonomik, toplumsal sorunlar arasında karşıllklı ilişkilerin bulunduğu gerçeğinin, Atatürk'ün öncülüğündeki Cumhuriyetin kurucu kadroları tarafından farkına varıldığı ve gereklerinin bir devlet politikası olarak yaşama geçirilmeye çalışıldığını göstermektedir. ${ }^{11}$

Türkiye Cumhuriyeti'nin sağlık hizmetleri konusunda benimseyeceği temel politika Mustafa Kemal Atatürk tarafindan TBMM'nin üçüncü y1lı (1 Mart 1922) açılış konuşmasında şöyle ifade edilmektedir;

"Efendiler,

Milletimizi asayişi tam halinde yaşatmak nuhbei amalimiz olduğu gibi onun slhhatine itina etmek ve vasaiti mevcudemiz nispetinde âlâmı içtimaiyesine çaresaz olmak da Hükümetimizin cümlei vazaifindendir. Bu cümleden olmak üzere memleketimizin etibba ihtiyacı imkânın müsaadesi nispetinde telâfiye uğraşıldı. 1336(1920) senesinde iki yüz altmış tabip müstahdemdi. Bu miktar, bu geçen sene zarfinda üç yüz on ikiye iblâğ edildi. Elli tabibin daha tedarikiyle hekimsiz kazalara izamları tasavvur edilmektedir. Bu sene emrazı sâriye istilâsına meydan verilmedi, başgösterenler derhal tedabiri sıhhiye ittihaziyle olduğ u yerde itfa olundu. Emrazı sâriyeye karşı en katî tedbir olan aşılar artık tamamiyle memleketimizde istihsal olunmaktadır. Üç milyon küsur kişilik çiçek aşısının Sivas'ta istihsal edilmiş olduğunu zikretmek bu bapta kâfi bir fikir verebilir. Memleketin malaryalı muhitlerinde miktarı kâfi kinin tevzi edildi. Frengi âfetinin itfası için de mümkün olan meblâğ sarf edildi. Ve emrazı içtimaiye ile mücadelemizin daha müsmir ve daha şâmil bir şekilde ifast esbabı da ihzar edilmiştir. Sıhhiye ve muaveneti içtimaiye hususatında takibettiğimiz gaye şudur: Milletimizin sıhhatinin muhafaza ve takviyesi, vefiyatın tenkisi, nüfusun tezyidi, emrazı içtimaiye ve sâriyenin gayrimüessir bir hale ifrağg, bu suretle efradı milletin dinç ve saye kabiliyettar bir halde sahihülbeden olarak yetiştirilmesi..”. Konuşmanın başka bir bölümünde de Mustafa Kemal Atatürk, ormanların toplum sağlığı açısından önemine vurgu yapmıştır ${ }^{12}$. O dönemde sağlığın korunması ve geliştirilmesine vurgu yapılmış olması çok önemlidir. Çünkü günümüzde de sağlığın korunması ve geliştirilmesi önemini ve önceliğini koruyan bir konudur.

\footnotetext{
${ }^{11}$ Erdem Aydın; Atatürk'ün "Sağlık Kavramı ve Anlayışı”, Ankara Tıp Mecmuası, 48, 1995, s. 45.

${ }^{12}$ TBMM; "Zabit Ceridesi", 1. 3. 1338 - 1 Mart 1922, s., 3 (tbmm.gov.tr/tutanaklar/TUTANAK, erişim tarihi:11.07.2011).
} 
Benimsenen politika, sağlık hizmetlerini devletin asli görevi olarak görmekte ve koruyucu sağlık hizmetlerine öncelik vermektedir. Bu politika Cumhuriyetin ilanından sonra Bakan olan Dr. Refik Saydam'ın desteği ile uygulanmaya başlamıştır. Cumhuriyet' in ilk yıllarında sağlık alanında karşı karşıya olunan en büyük sorun bulaşıcı hastalık salgınlarıdır. Savaşların sebep olduğu sosyo-ekonomik yıpranma, sağlık insan gücü ve kaynaklarının yetersizliği sağlık sorunlarının çözümünde en önemli engeller olarak sıralanmaktadır. Bu yıllarda Türkiye'de 554 hekim, 69 eczacı, 4 hemşire, 560 sağlık memuru ve 136 ebe bulunmaktadır. Ayrıca, 4.100 kişiye bir hastane yatağ 1 düşmektedir. ${ }^{13,14}$

$\mathrm{Bu}$ koşullar altında belirlenen politikada iki genel ilke benimsenmiştir. Bu ilkeler;

“......Yalnız memleketimizin umumi ve içtimai hıfzıssıhha işlerinde yapılacak şeyler pek çok ve hatta nihayetsiz olduğu için Sıhhat ve İçtimai Muavenet Vekaleti asri telakkilere uygun bir programla, ve en mühim işleri daha az mühimlerine takdim ederek mesai sahasına dahil olmak lüzumunu hissetmiş ve bu mesaisini zamanla ve maddi vesait arttıça o nispette arttırmak sureti ile hedefine doğru büyük mesafeler kateylemiştir" ${ }^{5} \mathrm{Bu}$ yaklaşımın günümüz literatüründeki karşıllı̆ı popüler kavramlar olan sağlık hizmetlerinde öncelik belirleme ve kaynak tahsisidir. Diğer ilke, “....büyük sthhat mücadelesi mesaisinde halka yaklaşmak ve halka sıhhat ve saadeti için lazımgelen bilgiyi vererek bu mücadelede onun yardımından istifade etmeğe büyük ehemmiyet verilmiștir"16 $\mathrm{Bu}$ ilkede günümüzde önemle vurgulanan sağlık eğitimi ve sağlık hizmetlerinde toplum katılımı anlayışının bir karşılığıdır.

$\mathrm{Bu}$ doğrultuda, 1924 y1lından itibaren hastanesi bulunmayan yerlerin sağlık hizmeti ihtiyacını bir ölçüde karşılayabilmek için ilçe merkezlerinden başlayarak, muayene ve tedavi evi (Dispanser) adı ile yeni sağlık üniteleri kurulmaya başlanmıştır. Muayene ve tedavi evleri esas olarak ayakta tedavi edici sağlık hizmeti sunan, 5 - 10 yataklı sağlık kurumlarıdır. Bu kurumlarda hasta muayenesi ücretsizdir. Yoksul hastaların ilaçları da parasız olarak verilir. Bu kurumlarda yatırılan hastalar, yalnız bir geceliğine olmak üzere, muayene olduktan sonra aynı gün köyüne dönemeyecek olanlar, kalacak yeri olmayan fakir hastalar ve hastaneye sevk edilecek olanların sevk gününe

\footnotetext{
${ }^{13}$ Türkiye Cumhuriyeti Sshhat ve İçtimai Muavenet Vekâleti, a.g.e., s. 3.

${ }^{14}$ Türkiye Cumhuriyeti Sağlık Bakanlığı; Sağlık Hizmetlerinde 50. Yıl, Sağlık ve Sosyal Yardım Bakanlığı Yayınları, No: 422, Ayyıldız Matbaası, Ankara, 1973, s., 317.

${ }^{15}$ Türkiye Cumhuriyeti Sihhat ve İçtimai Muavenet Vekâleti, a.g.e., s. 5.

${ }^{16}$ Türkiye Cumhuriyeti Sihhat ve İçctimai Muavenet Vekâleti, a.g.e., s. 111.
} 
kadar geçen süre için yatırılması gerekenlerdir. Muayene ve tedavi evlerinin hizmet verebilmesi için hekim bulunması zorunludur. Hizmet binalarının da yerleşim yerinin kolay ulaşılabilecek merkezi ve işlek bir yerinde bulunması esas k1lınmıştır. ${ }^{17}$

Belirlenen politika ve ilkeler 1925 yılında hazırlanan Sağlık Çalışma Programı'nda yedi temel hedef altında toplanmıștır. ${ }^{18}$

1 - Devlet sağlık örgütünü genişletmek,

2 - Hekim, sağlık memuru ve ebe yetiştirmek,

3 - Numune hastaneleri ile Doğum ve Çocuk Bakımevleri açmak,

4 - Sitma, Verem, Trahom, Frengi gibi önemli hastalıklarla mücadele etmek,

5 - Sağlık ile ilgili kanunları yapmak,

6 -Sağl1k ve sosyal yardım örgütünü köye kadar götürmek,

7 - Merkez Hıfzıssıhha Enstitüsü ve Hıfzıssıhha Okulu kurmak.

SSYB'nın merkez ve taşra teşkilatının yukarıda sayılan hedeflere ulaşmasını sağlayacak biçimde örgütlendiği, Şema 1 ve Şema 2'de verilen teşkilat yapılarında görülmektedir. ${ }^{19}$

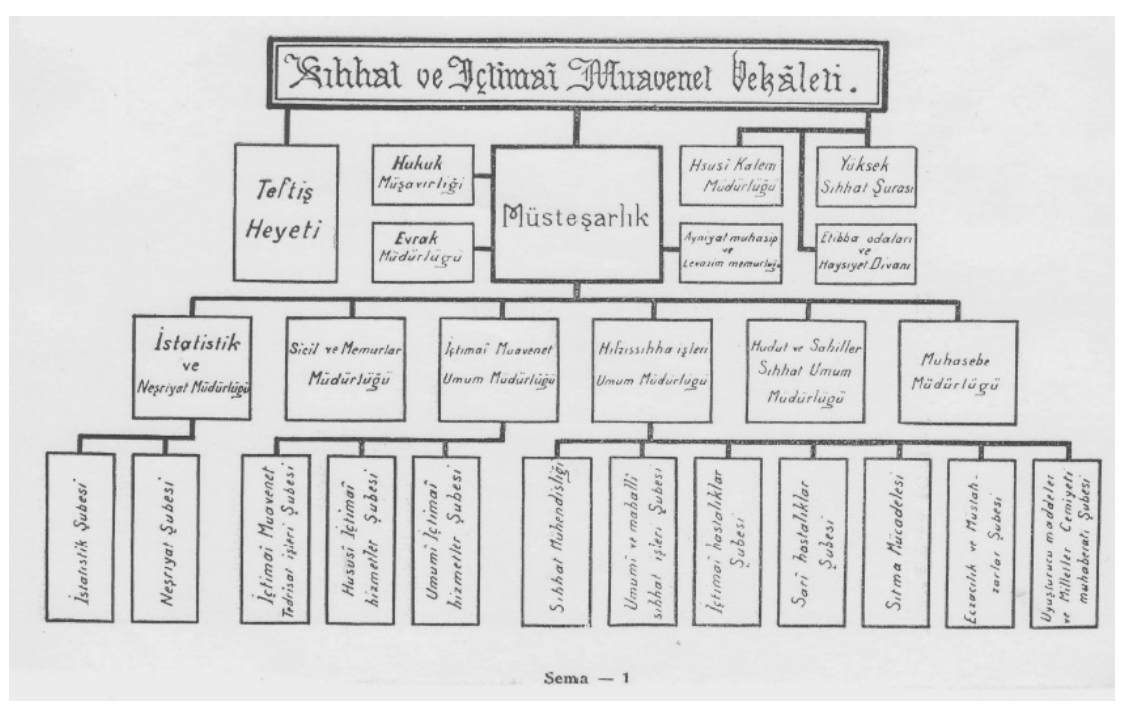

\footnotetext{
${ }^{17}$ Aydın, 2002, a.g.e., s. 37-39.

${ }_{18}$ Türkiye Cumhuriyeti Sağlık Bakanlığı, a.g.e., s. 38.

${ }^{19}$ Türkiye Cumhuriyeti Sihhat ve İçtimai Muavenet Vekâleti, a.g.e., s. 6, 8.
} 


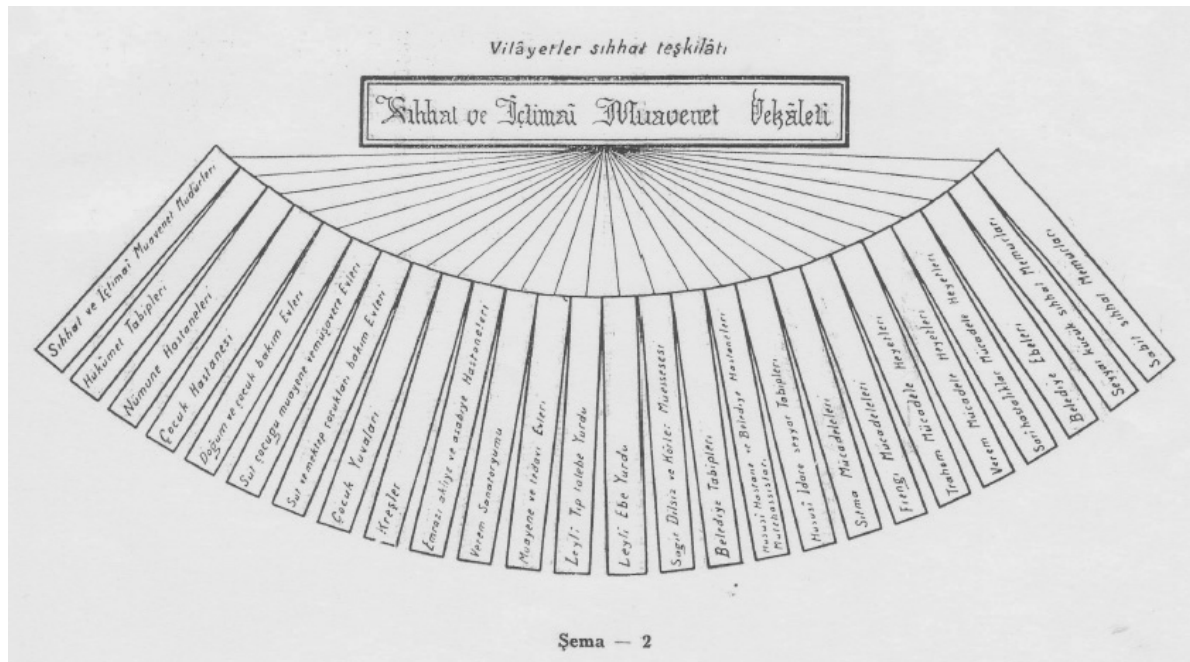

Teşkilat şemaları ve çalışma programında, koruyucu sağlık hizmetlerine öncelik verilmiş, sağlık hizmetleri genel olarak hastanelerin dışında planlanmıştır. Dr. Refik Saydam koruyucu ve tedavi edici sağlık hizmetlerini tüm ülkeye yaymak için büyük çaba sarf etmiştir. Bu amaçla yatay ve dikey örgütlemeyi bir arada uygulamıştır. Bir yandan verem, sıtma, trahom gibi hastalıklara karşı dikey örgütler oluşturulurken, diğer yandan koruyucu ve tedavi edici sağlık hizmetlerinin birlikte sunulduğu yatay örgütlenme devam etmiştir. $\mathrm{Bu}$ anlamda Osmanlı dönemindeki hükümet tabipliği birlikte seyyar tabiplik uygulaması başlatılmıştır. Amacı sağlı hizmetlerini köylere kadar vatandaşın ayağına götürmek olan seyyar tabiplik, finansmanı il özel idareleri tarafından sağlanmak üzere, Devlet tarafından tayin edilen hekimlerle uygulanan bir hizmet modelidir. Seyyar tabipler her ayın 20 günü köy ziyaretlerinde bulunmakta, ayakta tedavi, halk sağlığ 1 ve çevre sağlığ konularında hizmet yapmakta, ayrıca köylüye sağlık eğitimi vermektedir. $\mathrm{Bu}$ kapsamda yapılan muayene ve ilaçlar ücretsiz olarak verilmektedir. ${ }^{20}$

Ülkede sağlık alanında gerçekleştirilen kapsamlı çalışmalar, Atatürk'ün konuşmalarında da vurgulanmış ve yapılması gerekenler özellikle TBBM açılış konuşmalarında ifade edilmiştir. Örneğin, 1 Kasım 1928 tarihli TBMM açış konuşmasında; "Sıhhî mücadeleye gösterdiğiniz alâka ve memlekette bu yolda elde edilen neticeler bu mesaînin genişletilmesini lüzumlu göstermektedir. Bu sene umumî Hıfzıssıhha Kanunu Lâyihasının büyük

\footnotetext{
${ }^{20}$ Aydın, 2002, a.g.e., s. 34-36.
} 
Meclise takdimi mukarrerdir", ${ }^{21} 1$ Kasım 1929 tarihli konuşmasında; "Geçen sene memleketin sihhati, mühim bir arızadan müteessir olmaksızın geçmiştir. Her nevi sıhhî mücadeleyi, mümkün olan derecede, seri ve geniş bir surette takip etmek, başlıca hedeflerden olmaya lâyıktır", ${ }^{22}$ 1 Kasım 1932 tarihli konuşmasında; "İçtimâ̂ hastalıklar ile mücadele faaliyetini arttıracağız", 23 Kasım 1934 tarihli konuşmasında; "Ulusun, ulus gençlerinin, çocuklarının sağlıklart, sağlamlıkları, gürbü̈lükleri; üzerine; düştüğ̈̈müz çok gerekli bir diriklik iştir. (Sağllk Soysal Yardım Bakanlığının) bu yönden bize kıvanç verecek yolda çalışmakta olduğunu görmekteyiz", 24 Kasım 1935 tarihli konuşmasında; "Sağllk savaşı da yeni icablara göre genişletilmek zaruretindedir. Türke ev ve bark olan her yer sağllğın, temizliğin, güzelliğin, modern külttürün örneği olacaktır", ${ }^{25} 1$ Kasım 1937 tarihli konuşmasında; "Kendine, inkilabın ve inkilapçılığın çesitli ve hayati vazifeler verdiği Türk vatandaşının sağlı̆̆ı ve sağlamlığı, her zaman, üzerinde dikkatle durulacak milli meselemizdir. Sağllk ve Sosyal Yardım Vekâletinin bu mesele üzerindeki sistemli çalışmaları, yüksek Kamutayı memnun edecek mahiyette inkişaf etmektedir. Vekâletin, "Sağlam ve gürbüz nesil, Türkiye'nin mayasıdı" prensibini, pekiyi kavruyarak çalışmakta olduğunu takdire değer bulurum". ${ }^{26}$

Konuşmalarından da anlaşılacağı üzere, Atatürk sağlığı milli bir mesele olarak tanımlamakta ve ülkenin mayası olarak görmektedir. Bu nedenle sağl1k hizmetlerinin devletin asli görevi olduğunu ve sağlık mücadelesinin çağdaş gelişmelere uygun olarak seri olarak yürütülmesi gerektiğini ifade etmektedir. Bu dönemde hazırlanan 1921 ve 1924 anayasalarında sağlık ile ilgili açık bir düzenleme bulunmamaktadır. Yalnızca 1924 anayasasının 78. maddesinde, hastalık ve benzeri durumlarda halk sağlığını korumak üzere, bireyin yolculuk özgürlüğünün kayıt altına alınabileceği belirtilmiştir ${ }^{27}$. Sağlık ile ilgili düzenlemelerin tamamına Atatürk'ün bakış açısının hâkim

\footnotetext{
21 TBMM; "Zabıt Ceridesi”, 1 Teşrinisan (Kasım), 1928, $\quad$ s., 4 (tbmm.gov.tr/tutanaklar/TUTANAK, erişim tarihi:11.07.2011).

${ }^{22}$ TBMM; "Zabıt Ceridesi”, 1. 11. 1929, s., 3 (tbmm.gov.tr/tutanaklar/TUTANAK, erişim tarihi:11.07.2011).

${ }^{23}$ TBMM; "Zabut Ceridesi", 1. 11. 1932, s., 3 (tbmm.gov.tr/tutanaklar/TUTANAK, erişim tarihi:11.07.2011)

${ }^{24}$ TBMM; "Zabit Ceridesi", 1. 11. 1934, s., 4 (tbmm.gov.tr /tutanaklar/TUTANAK, erişim tarihi:11.07.2011)

${ }^{25}$ TBMM; "Zabıt Ceridesi”, 1. 11. 1935, s., 3 (tbmm.gov.tr/tutanaklar/TUTANAK, erişim tarihi:11.07.2011).

${ }^{26}$ TBMM; "Zabit Ceridesi", 1. 11. 1937, s., 3 (tbmm.gov.tr /tutanaklar/TUTANAK, erişim tarihi:11.07.2011).

${ }^{27}$ Suna Kili, A. Şeref Gözübüyük, Türk Anayasa Metinleri (Sened-i İttifaktan Günümüze), II. bask1, Türkiye İş Bankası Kültür Yayınları., İstanbul, 2000, s.136.
} 
olduğu görülmektedir. $\mathrm{Bu}$ anlamda, 1930 y1lında yürürlüğe girip halen yürürlükte olan Umumi Hıfzıssıhha Kanunu sağlığın anayasası olarak kabul edilmektedir. Bu kanunun 1. maddesi benimsenen felsefeye vurgu yapmaktadır. Buna göre, "Memleketin sıhhi şartlarını 1slah ve milletin sıhhatine zarar veren bütün hastalıklar veya sair muzır amillerle mücadele etmek ve müstakbel neslin sıhhatli olarak yetişmesini temin ve halkı tıbbi ve içtimai muavenete mazhar eylemek umumi devlet hizmetlerindendir.,28

$\mathrm{Bu}$ dönemde yapılan yasal düzenlemeleri konularına göre üç grupta toplamak mümkündür. ${ }^{29}$ (Türkiye Cumhuriyeti Sıhhat ve İçtimai Muavenet Vekâleti; 1933). Bunlar,

1. Doğrudan doğruya umumi hıfzıssıhha işlerine sari ve içtimai hastalıklarla mücadeleye mahsus kanunlar ve tüzükler. Bu kapsamda, Umumi Hifzıssihha Kanunu, Sitma Mücadele Kanunu, Su Kanunu, Uyuşturucu Maddeler Kanunu ve bu kanunların uygulamalarına yönelik tüzük ve yönetmelikler yer almaktadır.

2. Tababet ve şubeleri sanatlarının icrasına ait kanunlar ve tüzükler. $\mathrm{Bu}$ kapsamda, Tababet ve Şuabatıi Sanatlarının Tarzı İcrasına Dair Kanun, Eczacilar ve Eczaneler Kanunu, Ecza Ticarethaneleri Kanunu, Laboratuarlar Kanunu, Hususi Hastaneler Kanunu ve bu kanunların uygulamalarına yönelik tüzük ve yönetmelikler yer almaktadır.

3. Yardımcı kanunlar ve nizamnameler. Bu kapsamda, Rusumu Sihhiye Kanunu, Devlet Kinin Kanunu, Türk Kodeksi Kanunu, Tabiplerin Sitma Staj1 Kanunu, Türkiye Cumhuriyeti Merkez Hifzıssıhha Müessesi Kanunu, Tıbbi ve İspençiyarı Müstahzarlar Kanunu, Umuru Sihhiye Bütçeleri ve Memuruni Sıhhiye Hakkında Kanun, Tabiplerin Mecburi Hizmet Kanunu, Sihhat ve İçtimai Muavenet Vekâleti Teşkilat ve Memurin Kanunu ve bu kanunların uygulamalarına yönelik tüzük ve yönetmelikler yer almaktadır.

Yasal düzenlemelerin sağlı̆̆ın tüm alanlarına yönelik olduğu görülmektedir. Yapılan düzenlemeler ciddiyetle uygulanmıştır. Umumi Hıfzıssıhha Kanunu, Tababet ve Şubeleri Sanatlarının Tarzı İcrasına Dair Kanun, Hususi Hastaneler Kanunu gibi temel yasalar halen yürürlüktedir. Döneme ait sağlık politikaları ana hatları ile şöyle özetlenebilir ${ }^{30}$ (Fişek, 1991).

\footnotetext{
${ }^{28}$ Nedim Demirel, İlhan Yiğit, Faik Gözenman., Lütfi Tuncay; Sağlık Mevzuatımız, Filiz Kitabevi, İstanbul, 1969, s. 5.

${ }^{29}$ Türkiye Cumhuriyeti Sihhat ve İçtimai Muavenet Vekâleti, a.g.e., s. 16-27.

${ }^{30}$ Fişek, a.g.e., s. 2-3.
} 
Hükümet koruyucu hekimlik hizmetlerini, özellikle salgın hastalıklar ile savaş için kurduğu örgütleri genel bütçeden finanse etmiştir. Bu amaçla yurt çapında sıtma savaş teşkilatı, trahom ve frenginin yaygın olduğu bölgelerde trahom savaş ve frengi savaş örgütleri kurulmuştur. Ankara'da Hıfzıssıhha Enstitüsü kurularak bulaşıcı hastalıklar ile mücadele için laboratuvar hizmetleri, aşı ve serum üretilmesi sağlanmıştır. Hastane hizmetlerinin yürütülmesi belediye ve özel idarelere bırakılmıştır. Ayrıca, Türkiye Cumhuriyeti Devlet Demiryolları ve PTT gibi Kamu İktisadi Kuruluşlarının hastane kurmasına izin verilmiştir. SSYB öncülük etmek amacı ile Ankara, İstanbul, Sivas, Erzurum ve Diyarbakır'da olmak üzere beş Numune Hastanesi kurmuştur. Hekim gereksinimlerini karşılamak için hükümet tıp öğrencilerinin yeme, içme, giyinme ve barınma gereksinimlerini sağlamak amacı ile tıp öğrenci yurtları açmıştır. Öğrenciler bu yurtlarda ücretsiz kalmakta, mezun olduktan sonra dört y1l SSYB'nda zorunlu hizmet yapmakla yükümlü tutulmuştur. Hemşire, ebe gibi sağlık personeli yetiştirilmesi konusunda da çaba harcanmıştır. Bakanlık, koruyucu sağlık hizmetlerini hekimler için çekici hale getirmek amaciyla, devletin memurlara verdiği maaştan çok yüksek bir ücret sistemini kabul etmiştir. Bir sitma savaşı hekiminin maaşı validen fazla, trahom savaş teşkilatı başkanının maaşı ise, milletvekili maaşının 3 katı olarak uygulanmıştır. Hükümetin hekimlere verdiği bu ayrıcalıklı statü, sağlık hizmetlerine verilen önemin kanıtı olarak ifade edilmektedir.

Sağlık hizmetleri devletin asli görevleri arasında sayılmış, ancak özel sağllk sektörü de ihmal edilmemiştir. Nitekim halen yürürlükte olan Özel Hastaneler Kanunu 1933 yılında çıkarılmıştır. Diğer bir ifade ile Türkiye Cumhuriyeti Soyadı Kanunu'ndan önce Özel Hastaneler Kanunu'nu çıkarmıştır. Sağlık yönetiminin çağdaş bir düzeye ulaştırmak için 1935 yılında Hıfzıssıhha Okulu kurulmuştur. Okul, hekimlere ve diğer sağlık personeline kısa süreli kurslar veren bir kurum olarak hizmet vermiştir. Bütün çabalara karşın birinci basamak sağlık hizmetleri arzu edilen düzeyde iyi örgütlenememiştir. $\mathrm{Bu}$ hizmet hekim muayenehanelerinde, hastane polikliniklerinde ve dispanserlerde sürdürülmüştür.

Tüm bu gelişmeler yaşanırken, Kızılay'ın rolünü ve Kızılay'a verilen önemi de unutmamak gerekir. "Osmanlı Hilal-i Ahmer Cemiyeti", Cumhuriyetin kuruluşundan sonra, 1923 yılında "Türkiye Hilal-i Ahmer 
Cemiyeti"ne, 1935 y1lında ise Atatürk'ün teklifi ile "Türkiye Kızılay Cemiyeti"ne dönüştürülmüş ve faaliyetleri hıla artmıştır. ${ }^{31}$

\section{Sonuç}

Cumhuriyet tarihinde sağlık politikalarında önemli değişimler yaşanmıştır. Tarihsel süreç dönemler halinde incelendiğinde; Atatürk dönemi sağlık politikalarının etkili olduğu 1920-1945 yılları oldukça dikkat çekicidir. Ulusal Kurtuluş Savaşı devam ederken, Atatürk sağlık yapılanmasına ayrı bir önem vermiş̧ir. TBMM'nin açılmasından hemen sonra SSYB'nın kurulması sağlanmıştır. Bakanlık koruyucu sağlık hizmetlerine önem vermiş, en çok görülen, en çok öldüren, sakatlık ve komplikasyonlara yol açan, sıtma, verem, trohom ve frengi gibi hastalıklarla mücadele için, hastalıklara özgün sağlık örgütlenmesi gerçekleştirmiştir. Hastane, dispanser, hekim ve hekim dışı sağlik personelinin sayısının artırılması sağlanmıştır. Sağlık sektörünün her alanında ihtiyaç duyulan, bazılarının hala yürürlükte olduğu, temel yasalar hazırlanmış ve kararlılıkla uygulanmıştır. Atatürk dönemi sağlık politikasının, günümüz sağlık politikası ve planlamasına 1şık tutacak, örnek oluşturacak ve ders alınacak nitelikte olduğu görülmektedir.

\footnotetext{
${ }^{31}$ Umut Karabulut; "Cumhuriyetin İlk Yıllarında Sağlık Hizmetlerine Toplu Bir Bakış: Dr. Refik Saydam'ın Sağlık Bakanlığ 1 ve Hizmetleri (1975-1937)” ÇTTAD, VI/15, 2007, s. 158.
} 


\section{KAYNAKÇA}

Akdur, Recep; Sağlık Sektörü Temel Kavramlar, Türkiye ve Avrupa Birliği' nde Durum ve Türkiye'nin Birliğe Uyumu, Ankara Üniversitesi Avrupa Toplulukları Araştırma ve Uygulama Merkezi Araştırma Dizisi No:17, Ankara, 2003.

Aydın, Erdem; Türkiye'de Sağlık Teşkilatlanması Tarihi, Naturel Yayınları, Ankara, 2002.

Aydın, Erdem; “Atatürk'ün Sağlık Kavramı ve Anlayışı”, Ankara Tip Mecmuası, 48: 43-54, 1995.

Çağlayan, Suat; "Sağlık Yönetimi ve Sağllkta Yeniden Yapılanma", Yeni Türkiye, Sağlık Özel Sayısı, Sayı: 40, Temmuz - Ağustos, Ankara, 2001 ss.1196-1208.

Demirel, Nedim-Yiğit, İlhan- Gözenman, Faik-Tuncay, Lütfi; Sağlık Mevzuatımız, Filiz Kitabevi, İstanbul, 1969.

Fişek, Nusret; "Türkiye Cumhuriyeti Hükümetlerinde Sağllk Politikaları", Toplum ve Hekim, Sayı:48, 1991, ss.2-4.

Karabulut, Umut; "Cumhuriyetin Illk Ylllarında Sağlık Hizmetlerine Toplu Bir Baklş: Dr. Refik Saydam'ın Sağllk Bakanlı̆̆ ve Hizmetleri (1975-1937)" ÇTTAD, VI/15, 2007, ss. 151-160.

Kili, Suna-Gözübüyük, A. Şeref; Türk Anayasa Metinleri (Sened-i İttifaktan Günümüze), II. Baskı, Türkiye İş Bankası Kültür Yayınları., İstanbul, 2000.

Tatar, Mehtap; “Sağllk Politikası Nedir?”, Makro Bakış, 2, 2006, 22 - 23.

TBMM; "Zabit Ceridesi", $1.5 .1336 \quad 1 \quad$ Mayı 1920 , (tbmm.gov.tr/tutanaklar/TUTANAK, erişim tarihi:11.07.2011)

TBMM; "Zabit Ceridesi", 1. 3. 1338 - 1 Mart 1922, (tbmm.gov.tr/tutanaklar/TUTANAK, erişim tarihi:11.07.2011).

TBMM; "Zabıt Ceridesi", 1 Teşrinisan (Kasım), 1928 (tbmm.gov.tr/tutanaklar/TUTANAK, erişim tarihi:11.07.2011)

TBMM; "Zabıt Ceridesi”", 1. 11. 1929, (tbmm.gov.tr/tutanaklar/TUTANAK, erişim tarihi:11.07.2011).

TBMM; "Zabıt Ceridesi", 1. 11. 1932, (tbmm.gov.tr/tutanaklar/TUTANAK, erişim tarihi:11.07.2011).

TBMM; "Zabıt Ceridesi”", 1. 11. 1934, (tbmm.gov.tr/tutanaklar/TUTANAK, erişim tarihi:11.07.2011).

TBMM; “Zabıt Ceridesi”, 1. 11. 1935, (tbmm.gov.tr/tutanaklar/TUTANAK, erişim tarihi:11.07.2011). 
TBMM; "Zabıt Ceridesi”, 1. 11. 1937, (tbmm.gov.tr /tutanaklar/TUTANAK, erişim tarihi:11.07.2011).

Türkiye Cumhuriyeti Sıhhat ve İçtimai Muavenet Vekâleti; Sıhhiye Mecmuası Fevkalade Nüshası, Vekâletin 10 Yıllık Mesaisi, Hilal Matbaası, İstanbul, 1933.

Türkiye Cumhuriyeti Sağlık Bakanlığı; Sağlık Hizmetlerinde 50. Yıl, Sağlık ve Sosyal Yardım Bakanlığı Yayınları, No: 422, Ayyıldız Matbaası, Ankara, 1973. 